DOI: $10.1590 / 1809-6891 v 15 i 326398$

\title{
PREGNANCY RATES IN CRIOLLO BREED MARES AFTER ULTRASOUND-GUIDED FOLLICULAR ASPIRATION
}

\author{
Vivian CAmpos Laia Franco ${ }^{1}$, Fabrício Desconsi MozZaQuatro ${ }^{2}$, Rodrigo ARruda DE

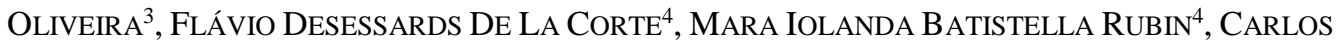 \\ ANTONIO MONDINO SILVA ${ }^{4}$
}

\author{
${ }^{1}$ Médica Veterinária Mestre, Niterói, RJ, Brasil - vivianclfranco@ yahoo.com.br \\ ${ }^{2}$ Professor Doutor da Universidade Estadual de Santa Catarina, Lages, SC, Brasil. \\ ${ }^{3}$ Professor Doutor da Universidade de Brasília, Brasília, DF, Brasil. \\ ${ }^{4}$ Professores Doutores da Universidade Federal de Santa Maria, Santa Maria, RS, Brasil.
}

There are few studies about transvaginal ultrasoundguided follicle aspiration in equine medicine regarding potential complications to future fertility of aspirated mares. In order to evaluate the effect of follicular aspiration on subsequent fertility in mares, two experiments were conducted. In Experiment I, fifteen Criollo mares were allocated to one of three groups according to the diameter of the aspirated follicle during estrus: $25-29 \mathrm{~mm}(\mathrm{n}=4$; Group 1); 30-34mm ( $\mathrm{n}=6$; Group $2)$; $\geq 35 \mathrm{~mm}(\mathrm{n}=5$; Group 3$)$ and control group $(\mathrm{n}=15$; Group 4). In Experiment II, the follicular aspiration was attempted in twenty-five mares during diestrous, when at least four follicles $(\geq 5 \mathrm{~mm})$ were seen in the transrectal ultrasonography of both ovaries. All visible follicles, between 4 and $8 \mathrm{~mm}$, were aspirated. Thirty-one mares served as control. In Experiments I and II, the pregnancy rates in the following cycle after aspiration were $75.0 \%$ (Group 1), 83.3\% (Group 2), 60.0\% (Group 3), and 73.3\% (Group 4 - Control); and $76.0 \%$ in the aspirated diestrous group and $77.4 \%$ in the control group (non aspirated), respectively. On both experiments, pregnancy rates were similar $(\mathrm{P}>0.05)$ in treated and control mares. The results of this study show that the conception rates of the first estrus period following follicular aspiration are not affected by the procedure.

KEYWORDS: equine, fertility, follicular aspiration, mares.

\section{TAXA DE GESTAÇÃO EM ÉGUAS DA RAÇA CRIOULA APÓS ASPIRAÇÃO FOLICULAR GUIADA POR ULTRASSOM}

\section{RESUMO}

Há poucos estudos sobre aspiração folicular transvaginal guiada por ultrassom na medicina equina abordando complicações futuras na fertilidade das éguas aspiradas. Com o objetivo de avaliar o efeito da aspiração folicular na fertilidade das éguas, foram conduzidos dois experimentos. No experimento I, 15 éguas da raça Crioula foram distribuídas em três grupos de acordo com o diâmetro do folículo aspirado durante o estro: $25-29 \mathrm{~mm}$ $(\mathrm{n}=4$; grupo 1$) ; 30-34 \mathrm{~mm}(\mathrm{n}=6$; grupo 2$)$; $\geq 35 \mathrm{~mm}(\mathrm{n}=5$; grupo 3) e grupo controle ( $\mathrm{n}=15$; grupo 4). No experimento II, a aspiração folicular foi realizada em 25 éguas durante o diestro quando pelo menos 4 folículos ( $>5 \mathrm{~mm}$ ) foram observados na ultrassonografia transretal em ambos os ovários. Foram aspirados todos os folículos 
visíveis, entre 4 e $8 \mathrm{~mm}$. Trinta e uma éguas serviram como controle. No experimento I, a taxa de prenhez no ciclo seguinte a aspiração foi de $75 \%$ (grupo 1), 83,3\% (grupo 2), 60\% (grupo 3), e 73,3\% (grupo 4). No experimento II foi de $76 \%$ no grupo aspirado e $77,4 \%$ no grupo controle (não aspirado). Em ambos os experimentos, as taxas de prenhez foram similares $(\mathrm{P}>0,05)$. Os resultados mostram que a taxa de concepção no primeiro ciclo após a aspiração folicular não é afetada pelo procedimento.

PALAVRAS-CHAVE: Aspiração folicular, éguas, equino, fertilidade.

\section{INTRODUCTION}

There is an increasing demand for assisted reproduction techniques in the equine breeding industry, including the ultrasound-guided transvaginal oocyte aspiration. The ability to collect oocytes directly from the follicle of live mares (OPU) is a viable alternative for subfertile mares with poor reproductive performance. In addition, in vitro fertilization (IVF) programs are not well established for the horse and the results are poor, thus recovered oocytes are frequently used in Gamete Intrafallopian Transfers (GIFT) ${ }^{1}$.

The first attempts of transvaginal oocyte recovery in horses were described in $1992^{2}$. Although OPU offered a repeatable, less invasive and less traumatic way to provide a source of oocytes ${ }^{1-5}$, some studies reported complications after using the technique in mares, as well as in cows and humans ${ }^{6-9}$.

In equine medicine there are some studies on follicular aspiration ${ }^{3-5,10}$, therefore many questions remain about possible effects on the mare's fertility following the procedure. There is few information in the literature about Criollo mares and their physiological characteristics, as well as their response to the follicular aspiration procedure. The increasing commercial value of the brood mares has put pressure on breeders, who need to improve the reproductive management of their animals and the genetic value of the offspring.

The aim of this study was to investigate the potential effects of follicular aspiration on conception rates of the following cycle after aspiration in Criollo mares.

\section{MATERIAL AND METHODS}

Non-pregnant healthy Criollo mares $(\mathrm{n}=86)$ between 5 and 22 years of age with body weight ranging from $350-460 \mathrm{~kg}$ were used. All mares were kept on pasture without supplementation.

The research was conducted during the reproductive season between October (2004) and February 2005, in the town of Uruguaiana-RS (latitude $30^{\circ} 12^{\prime} 26^{\prime \prime} \mathrm{S}$ and longitude $57^{\circ} 33^{\prime} 17^{\prime} \mathrm{W}$ ), southern Brazil.
The mares were examined daily by palpation per rectum to assess the uterine size, consistency, symmetry and to observe follicular dynamics. The presence and diameter of follicular structures were observed by ultrasound exam with $5 \mathrm{MHz}$ linear rectal transducer.

Before follicular aspiration, mares were restrained in stocks and submitted to epidural anesthesia using $5 \mathrm{~mL}$ of lidocaine $2 \%$ without epinephrine (Dorfin - Hertape Calier Saúde Animal S/A, Juatuba, Minas Gerais, Brazil) associated with previous sedation with xylazine 10\% (Sedomin König do Brasil LTDA, Santana do Parnaíba, São Paulo, Brazil) $(0.45 \mathrm{mg} / \mathrm{kg}$, iv) and acepromazine (Acepran 1\% - Vetnil, Louveira, São Paulo, Brazil) $(0.05 \mathrm{mg} / \mathrm{kg}$ iv). The tail of the mare was wrapped, fecal material was removed from the rectum, and the vulva and perineal area were cleaned using a dry paper towel.

The follicular aspiration procedure was performed with an ultrasonic device (Falcon 100 Esaote Europe B.V., Philipsweg, Maastricht, Netherlands). The system was equipped with a 5 $\mathrm{MHz}$ sector transducer, a stainless steel aspiration guide, a vacuum pump (COOK-VMAR500 - Cook Australia PTY LTD, Queensland, Australia), a silica tube, and a single lumen 16 gauge needle. The vacuum pressure was adjusted to $150 \mathrm{mmHg}$.

The aspiration guide was inserted into the vagina and placed in the vaginal fornix moving the transducer toward the ovary to be aspirated. The follicles were lined up to the ultrasound-guided needle by manual manipulation of the ovary per rectum. When in proper position, the needle was pressed against the wall of the vagina, introduced into the ovary, inserted into the follicle and the follicular fluid was then aspirated. The search of the oocyte has not been made because the aim of this study was not to evaluate the rate of oocyte recovery.

Before aspiration and eight days after follicular aspiration, all mares underwent a breeding soundness examination: clinical and ultrasonographic examination of the genital tract, bacteriological examination and biopsy of the endometrium. These procedures were used to confirm that uterine pathologies did not influence fertility ${ }^{11}$. No pathological findings were observed by 
clinical and ultrasonographic examination, all endometrial swabs were negative for bacteriological culture and endometrial biopsy's score was Category I and $\mathrm{II}^{12}$.

To evaluate the effect of follicular aspiration on subsequent fertility in mares, two experiments were conducted. Experiment I was conducted during the 2004 breeding season, with thirty Criollo mares. Fifteen mares were allocated to one of three groups according to the diameter of the aspirated follicle: 25-29mm ( $\mathrm{n}=4$; Group 1); 30-34mm ( $=6$; Group 2) or $\geq 35 \mathrm{~mm} \mathrm{(} \mathrm{n}=5$; Group 3), all of them were in estrus. Another group of fifteen mares had no aspiration performed and served as control. Only the dominant follicle was aspirated, defined as the largest follicle present for two consecutive days with diameter $\geq 25 \mathrm{~mm}$.

Four days after the follicular aspiration, the mares were examined by ultrasonography to verify the presence of an apparent physiological, normal looking, Corpus luteum (CL) and follicular development, according to the classification proposed by Mozzaquatro et $\mathrm{al}^{5}$. All aspirated mares received $1.0 \mathrm{ml}$ of Prostaglandine $\mathrm{F}_{2} \alpha$ (Lutalyse Pfizer Animal Health, Lincoln, USA) eight days after follicular aspiration to induce luteolysis of the induced CL.

On D9 (D0=day of follicular aspiration) the mares were again examined daily by rectal palpation and ultrasonography to observe if any lesion on the ovaries remained from aspiration, monitor the follicular growth and identify the optimal time for breeding. The mares were inseminated 24-48 hours before ovulation with semen from a known fertility stallion.

Experiment II was conducted during a period of three months (September-November 2005), fiftysix mares were used. Follicular aspiration was performed on twenty-five mares and the remaining thirty-one had no aspirations performed (serving as controls). Aspirations were carried out during diestrous, when at least 4 follicles $(\geq 5 \mathrm{~mm})$ were seen in the transrectal ultrasonography of both ovaries. All visible follicles were aspirated. On average 4-8 follicles per ovary were aspirated. The smallest follicles were aspirated first to facilitate the ovarian manipulation.

On D1, D4 and D8 ( $\mathrm{D} 0=$ aspiration day), the mares underwent rectal and ultrasonography examination to monitor for complications and to evaluate ovarian sensitivity to palpation. From D9 on, the mares were examined daily with the same objective as the first experiment.

The chi-square test was used in Software of the Statistical Analysis System Institute Inc (SAS) for all statistical procedures.

\section{RESULTS AND DISCUSSION}

Follicular aspiration was carried out on 40 Criollo mares for a total of 310 follicles (15 estrous and 295 diestrous). The uterine bacteriological exam showed no signs of uterus contamination in any of the mares. No alteration was found in the endometrial biopsies ${ }^{11}$.

In mare's ovaries from Experiment I, an echoic structure was found filling the space previously occupied by the aspirated follicle four days after aspiration, morphologically similar to those corpora lutea formed after physiological ovulations. In Experiment II, this behavior was not observed, possibly because the follicles aspirated on diestrous did not have a total luteinization hormone (LH) receptor formation or stimulation of granulosa cells for proper luteinization ${ }^{13}$. As observed by ultrasonography, no visible ovarian pathology changes caused by aspiration procedure were detected in the mares from Experiment I.

In Experiment II, on days 1 and 4, an increased ovarian sensitivity was observed in seven mares, making the exam of reproductive tract more difficult. Two of the 25 aspirated mares (12.5\%) demonstrated complications after the procedure. One mare showed ovarian pain elicited by palpation per rectum, progressive weight loss, weakness, and a trabecular mass full of fluid in the abdominal cavity observed by rectal palpation and ultrasonography. Later on, this mare died due to an abscess located in the pelvic region. This was probably due to the direct introduction of vaginal bacteria into the peritoneal cavity through the collecting needle. Similar facts were described by Weber et $\mathrm{al}^{8}$, where 3 mares $(12.5 \%)$ showed similar clinical signs and one mare (4.2\%) was euthanized because of complications.

In the present study, the other mare that developed problems after the aspiration procedure showed ovarian sensitivity in the right ovary the day after aspiration. An ovarian hematoma was diagnosed through ultrasonography and the mare recovered fully after 20 days.

Following the breeding management of the farm, the pregnancy diagnosis in Experiment I was performed only 30 days after the last service through rectal palpation and ultrasonography. Considering the aspirated and non-aspirated mare groups, $73.3 \%$ of them were pregnant and no difference was found between groups $(\mathrm{P}>0.05$; Figure 1). The pregnancy rates in Experiment II (Figure 2) did not differ between aspirated $(76.0 \%)$ and control mares (77.4\%). The number of punctures did not affect ovarian function as it is shown in the results. 


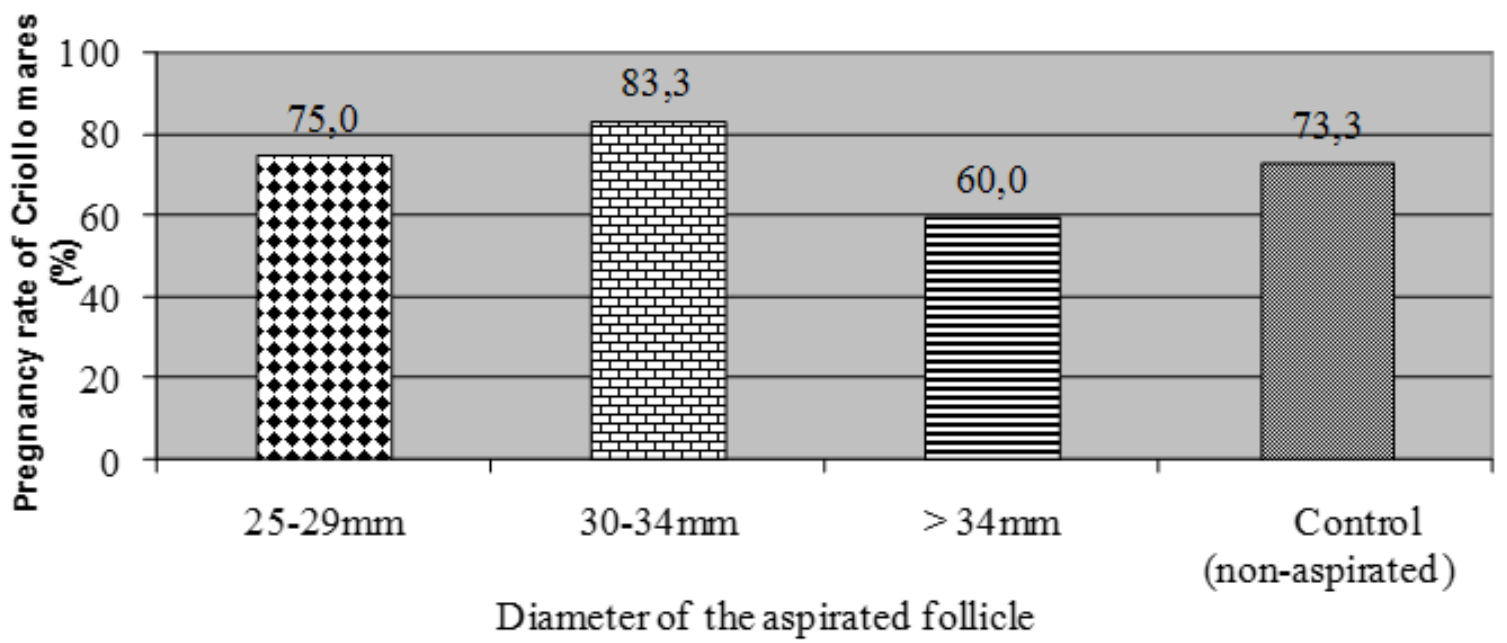

Figure 1. Effect of follicular aspiration during estrous on subsequent fertility of Criollo mares.

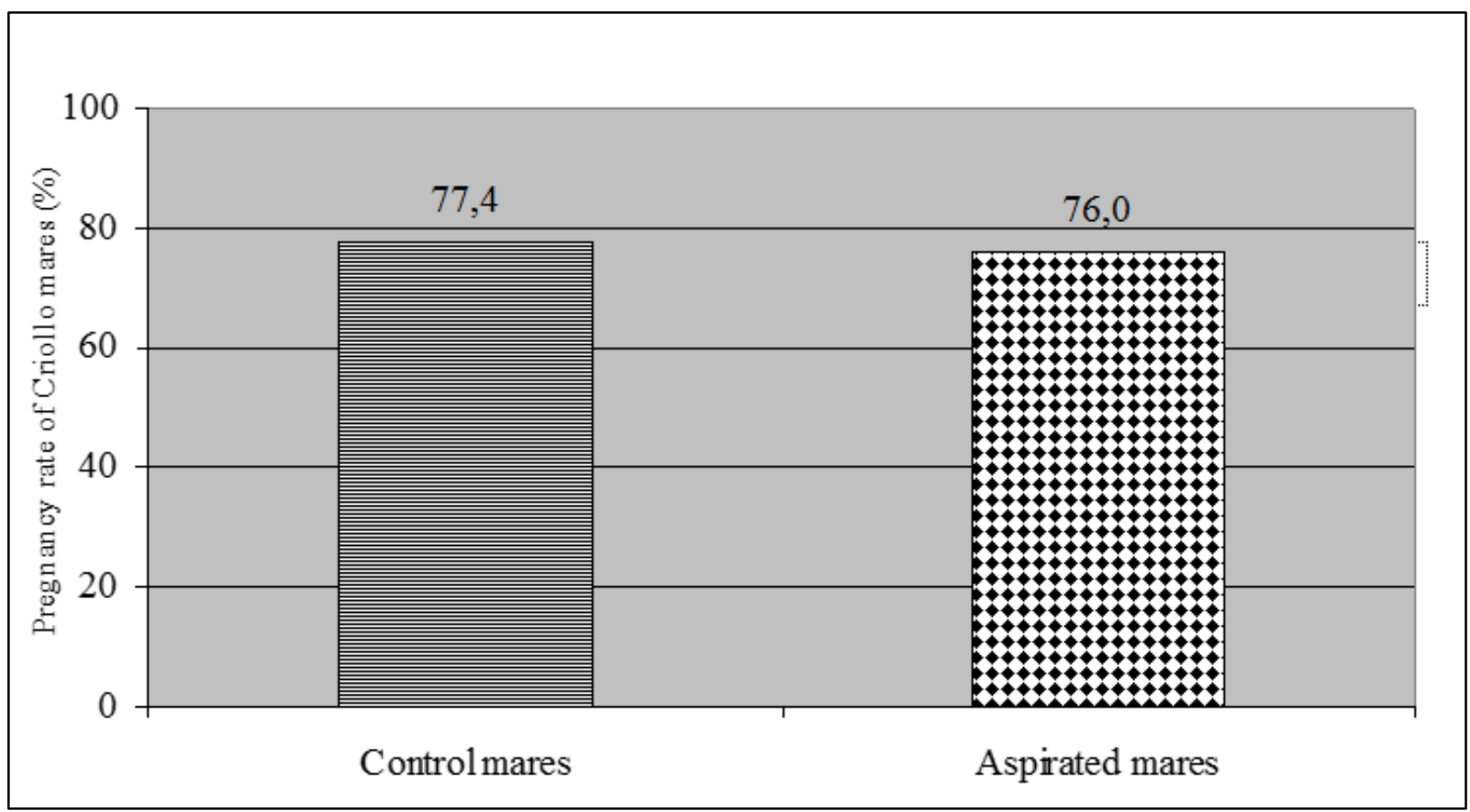

Figure 2. Fertility of control group and mares whose follicles were aspirated during diestrous.

\section{CONCLUSION}

The ovarian lesions caused by the collecting needle did not influence ovarian function in the following cycle and did not interfere directly with fertility. It should be applied with caution, minimizing the risk of serious complications, which cannot be ignored.

\section{ACKNOWLEDGEMENTS}

The authors acknowledge the kindness provided by Jorge Martins Bastos from Cabanha Santo Angelo, Uruguaiana/RS, Brazil, for supplying the mares used in this research. This research was sponsored by Embryolab/UFSM-RS/Brazil. CAPES provide scholarship to the first author. 


\section{REFERENCES}

1. Carnevale EM, Ginther OJ. Use of a linear ultrasonic transducer for the transvaginal aspiration and transfer oocytes in the mare. J. Equine Vet. Sci. 1993, 13(6): 331$333 . \quad$ Available in: http://www.sciencedirect.com/science/article/pii/S073708 0606811184\#.

2. Brück I, Raun K, Synnestvedt B, et al. Follicle aspiration in the mare using a transvaginal ultrasound guided technique. Equine Vet. J. 1992, 24(1): 58-59. Available

http://www.ncbi.nlm.nih.gov/pubmed/1555542.

3. Gaetano M, Barbara M, Eleonora I, et al. Fertility in the mare after repeated transvaginal ultrasound-guided aspirations. Anim. Reprod. Sci. 2005, 88(3/4): 299-308. Available in: http://www.sciencedirect.com/science/article/pii/S037843 2005000254.

4. Mozzaquatro FD, Verstegen JP, Douglas RH, et al. Luteal function induced by transvaginal ultrasonic-guided follicular aspiration in mares. Anim. Reprod. Sci. 2010, 119(1/2): 56-62. Available in: http://www.sciencedirect.com/science/article/pii/S037843 2009003042.

5. Mozzaquatro FD, Verstegen JP, Douglas RH, et al. Progesterone production in mares and echographic evaluation of the corpora lutea formed after follicular aspiration. Reprod. Dom. Anim. 2012, 47(2): 288-292. Available

http://onlinelibrary.wiley.com/doi/10.1111/j.14390531.2011.01856.x/pdf.

6. Bennett SJ, Waterstone JJ, Cheng WC, et al. Complications of transvaginal ultrasound-directed follicle aspiration: a review of 2670 consecutive procedures. J. Assist. Reprod. Genet. 1993, 10(1): 72-77. Available in: http://www.ncbi.nlm.nih.gov/pubmed/8499683.

7. Dicker D, Ashkenazi J, Feldberg D, et al. Severe abdominal complications after transvaginal ultrasonographically guided retrieval of oocytes for in vitro fertilization and embryo transfer. Fertil. Steril. 1993, 59(6): 1313-1315. Available in: http://www.ncbi.nlm.nih.gov/pubmed/8495784.
8. Weber JA, Causey RC, Emmans EE. Induction of luteolysis in mares by ultrasound-guided intraluteal treatment with PGF2 $\alpha$. Theriogenology. 2001, 55(9): 1769-1776. Available in: http://ac.elscdn.com/S0093691X01005192/1-s2.0-

S0093691X01005192-main.pdf? tid=b0e1bf04-39ee-

$11 \mathrm{e} 4-80 \mathrm{~b} 4-$

00000aab0f02\&acdnat $=1410465986 \_$dcb5ec20727843006 6d159ccbc705dba.

9. Vanderwall DK, Woods GL. Severe internal hemorrhage resulting from transvaginal ultrasound-guided follicle aspiration in a mare. J. Equine Vet. Sci. 2002, 22(2): 84-86. Available in: http://ac.elscdn.com/S0737080602700944/1-s2.0-

S0737080602700944-main.pdf? tid $=064 \mathrm{c} 2 \mathrm{f} 42-39 \mathrm{ef}-$

11e4-b3f2-

00000aab0f01\&acdnat $=1410466129 \quad 67 \mathrm{~b} 3 \mathrm{aa} 88431392 \mathrm{f} 1 \mathrm{a}$ 70c274621a0d28d.

10. Velez IC, Arnold C, Jacobson CC, et al. Effects of repeated transvaginal aspiration of immatures follicles on mare health and ovarian status. Equine Vet. J. 2012, 44: 78-83. Available in: http://www.deepdyve.com/lp/wiley/effects-of-repeatedtransvaginal-aspiration-of-immature-follicles-onXcix1Ms1pk.

11. Silva CAM, Barros SS., Esquerre RA, et al. A biópsia endometrial na avaliação da fertilidade na égua. Pesq. Vet. Bras. 1987, 7(4): 131-133. Available in: http://www.scielo.br/scielo.php?script=sci nlinks\& $\&$ ref $=00$ 0112\&pid=S0100-736X200700120000700030\&lng=pt.

12. Kenney RM. Cyclic and pathologic changes of the mare endometrium as detected by biopsy, with a note on early embryonic death. J. Am. Vet. Med. Assoc. 1978, 172(3): 241-262. Available in: http://www.ncbi.nlm.nih.gov/pubmed/621166.

13. Goudet G, Bézard J, Duchamp G, et al. Equine oocyte competence for nuclear and cytoplasmic in vitro maturation: effect of follicle size and hormonal environment. Biol. Reprod. 1997, 57(2): 232-245. Available in: http://www.biolreprod.org/content/57/2/232.long. 